\title{
"Responding to an Epidemic Requires a Compassionate State": How Has the Indian State Been Doing in the Time of COVID-19?
}

\section{JOHN HARRISS}

In response to the COVID-19 pandemic, the Indian government, led by Narendra Modi, imposed a stringent lockdown with only four hours notice. It paid no attention to the millions of migrants who work on a temporary basis in Indian cities. Most lost their livelihoods as a result of the lockdown, and millions sought to return to their native villages. At the same time, the rural economy confronted its own difficulties caused by the lockdown. The relief that the Modi government offered to the large numbers of poor people who had been adversely affected by its response to COVID-19 was limited and poorly delivered. The episode showed the lack of responsiveness of Indian democracy to the needs of working people and the failures of development. Yet Modi's particular brand of authoritarian populism worked so well that a government displaying very little compassion retained strong popular support.

Keywords: Authoritarian populism, circular migration, citizenship, democracy, informal economy, Narendra Modi

$\mathrm{T}$

THE STATEMENT THAT I have taken as the title of this essay was made by Yamini Aiyar, the president and chief executive officer of the internationally highly regarded Centre for Policy Research in Delhi. Aiyar argued in the same newspaper article, "a democracy that treats its citizens with callousness and a complete lack of compassion cannot survive."1 How has India been doing in this regard, at the time of this writing in the spring of 2020? Aiyar thought that the Indian state had failed the test. If she is right, what does this tell us about the character of Indian democracy?

My aim in this short article is to review evidence on the way the Indian state has treated its citizens during the COVID-19 pandemic and to reflect upon the political implications of its actions. I review the events of the crisis and the actions of the government both in the context of ongoing efforts by the Narendra Modi regime to establish a majoritarian Hindu state and in light of scholarship showing that the great majority of working Indians do not enjoy substantive citizenship. ${ }^{2}$ This is true especially for India's very many circular migrants, who have long been disenfranchised in their places of

John Harriss (jharriss@sfu.ca) is Professor Emeritus of International Studies at Simon Fraser University.

${ }^{1}$ Yamini Aiyar, “The State Needs to Step Up, Urgently," Hindustan Times, April 16 2020, https:// www.hindustantimes.com/columns/the-state-needs-to-step-up-urgently-opinion/story-UQhi5oyhA 61C52vU7fDxJO.html (accessed July 24, 2020).

${ }^{2}$ See Jonathan Parry, Classes of Labour: Work and Life in a Central Indian Steel Town (Delhi: Social Science Press, 2019). 
work and therefore have rarely commanded much recognition from politicians. They have, in many ways, been invisible.

India started this third decade of the twenty-first century in a state of turmoil. The economy was in quite poor shape - the growth rate dropped below 5 percent in 2019 and there were indications that poverty was increasing once again. A study of data from a survey of consumer expenditure in 2017-18, the results of which the government sought to withhold from the public, suggests that nationally, income poverty increased again after 2011-12. ${ }^{3}$ In this troubling context, the country was also experiencing heightened political tension, brought about particularly by the opposition mobilized across the country to the government's intention to change the citizenship laws in a way that was widely seen as discriminating against Muslims. ${ }^{4}$ The most notable site of opposition was Shaheen Bagh in Delhi. It was largely in response to this opposition, and following incitement by local leaders from the ruling Bharatiya Janata Party (BJP), that Delhi experienced the worst Hindu-Muslim communal violence in decades. ${ }^{5}$ These events took place in February 2020, at the same time that Prime Minister Modi was meeting President Donald Trump in a series of much-hyped encounters. It was in this context that the coronavirus pandemic began to take hold in the country.

The first case of COVID-19 in India was reported in Kerala on January 30, 2020, but the first death, in Karnataka, did not occur until March 12. Even on March 13, the Ministry of Home Affairs maintained that the country was not yet experiencing a health emergency. It was an unfortunate coincidence that on the same day, a very large gathering took place in Delhi, organized by the Muslim evangelical organization Tablighi Jamaat. It subsequently proved to be the case that this was a particularly important source of infection. This event-which coincided, it must be said, with very large gatherings at Hindu religious sites on the same day-was cynically exploited, once its consequences became known, to stoke communalism. The prominent television news anchor Arnab Goswami, for instance, claimed that people were dying "because of the singular determination of the Tablighi Jamaat to spread the virus in our country." 6 The idea that it was Muslims who had brought COVID-19 to India provided some cover for the government, which did very little to check such accusations or the subsequent wave of Muslim-baiting on social media (just as it had ignored the incitement to violence against anti-government protesters before the Delhi riots). The circumstances of the epidemic were also exploited by the government to stifle opposition by closing down dissent

\footnotetext{
${ }^{3}$ On the slowdown of the economy, see Arvind Subramanian and Josh Felman, "The Great Slowdown" (Faculty Working Paper 370, Centre for International Development at Harvard University, December 2019); on poverty, see S. Subramanian, "What Is Happening to Rural Welfare, Poverty and Inequality in India?," India Forum, December 6, 2019, https://www.theindiaforum.in/article/what-happenedrural-welfare-poverty-and-inequality-india-between-2011-12-and-2017-18 (accessed July 23, 2020).

${ }^{4}$ See Niraja Gopal Jayal, "Faith-Based Citizenship," India Forum, November 1, 2019, https://www. theindiaforum.in/article/faith-criterion-citizenship (accessed July 23, 2020).

5“Delhi's Muslims Despair of Justice after Police Implicated in Riots," The Guardian, March 16, 2020, https://www.theguardian.com/world/2020/mar/16/delhis-muslims-despair-justice-policeimplicated-hindu-riots (accessed July 23, 2020).

${ }^{6}$ Asim Ali, "Coronavirus Was a Test of Secular Nationalism," ThePrint, April 1, 2020, https:// theprint.in/opinion/coronavirus-test-of-secular-nationalism-tablighi-jamaat-became-scapegoat/ 392764/ (accessed July 23, 2020).
} 
in the media ${ }^{7}$ and arresting critics on what appeared to be very flimsy grounds. ${ }^{8}$ There were no signs, in these developments, of a "compassionate state."

On March 14, notwithstanding the Home Ministry's announcement of the previous day - that India was not yet facing a health emergency — the central government declared COVID-19 a "notified disaster." By that time, about a dozen states were under partial lockdown. Thereafter, events began to accelerate. On March 19, the prime minister proposed in a television address to the nation a daylong "janata curfew" on Sunday, March 22. People were asked to come out of isolation on that day at 5:00 p.m. to clap their hands or bang thalis (metal plates) to applaud those working in essential services. This was just the first of the exercises in political theater that Modi set up to build a sense of national solidarity around a focus on himself. It was followed by his announcement on March 24 of a complete lockdown of the country for twenty-one days, starting just four hours later, on March 25. This was to be the most stringent lockdown in the world. ${ }^{9}$

The way the lockdown was announced displayed middle-class bias. The noted commentator Pratap Bhanu Mehta wrote, "We were given more time to prepare for the banging of utensils, than migrant labour was given to reach home." 10 Even before the announcement of the lockdown, Indian Railways had canceled all passenger trains from midnight on March 23, and reports were already coming in of migrant workers trying to return to their homes. On March 24, the economist Jayati Ghosh said in an interview that the situation the country was facing would be like "falling off a cliff," with a demand shock and disruption of supply chains occurring at the same time and a massive spike in unemployment. ${ }^{11}$

It appeared that the government had given no thought to the implications of the lockdown for very large numbers of working people in the cities; to what would happen to their employment; to the possibility that without their daily wages, they would be unable to buy food; or to the fact that the social distancing that was being enjoined on everyone would be impossible for them and for so many other people living in urban slums. Certainly no thought had been given to the possibility that many migrant workers would seek to return to their distant village homes, with profoundly important consequences for the spread of the disease. But by March 25, pictures

\footnotetext{
${ }^{7}$ Vindu Goel and Jeffrey Gettleman, "Media Dissent Fades as Modi Tightens Grip,” New York Times, April 3, 2020, https://www.nytimes.com/2020/04/02/world/asia/modi-india-press-media. html (accessed July 23, 2020).

8“India's Government Is Better at Curbing Critics than COVID-19," The Economist, May 9, 2020, https://www.economist.com/asia/2020/05/09/indias-government-is-better-at-curbing-critics-thancovid-19 (accessed July 23, 2020).

${ }^{9}$ The most stringent according to data collected by the Blavatnik School of Government of the University of Oxford, reported daily in the Financial Times throughout the pandemic.

${ }^{10}$ Pratap Bhanu Mehta, "Lockdown Announcement Has Not Been Matched by a National Strategyon Containing Fallout for the Poor," Indian Express, March 28, 2020, https:/indianexpress.com/ article/opinion/columns/india-lockdown-coronavirus-threat-covid-19-spread-6335042/ (accessed July $24,2020)$

${ }^{11}$ Jayati Ghosh interviewed by Karan Thapar, The Wire, March 24, 2020, https://thewire.in/ economy/coronavirus-lockdown-has-already-done-more-damage-to-economy-than-demonetisation (accessed July 24, 2020).
} 
began to appear of large numbers of migrant workers taking to the highways to walk home. Others were reported to be holed up in their dwellings or their workplaces without work or food, in fear of the police if they ventured outside. ${ }^{12}$ For the police, the lockdown was an occasion for unleashing sometimes brutal violence against innocent citizens. ${ }^{13}$

The numbers of those on the move continued to mount, however, and on March 27, the Ministry of Home Affairs asked states to stop the mass exodus. The government then issued instructions to the states to set up camps for migrant workers and to provide medical care and clothing. But reports showed that people still continued to move in large numbers for several days. ${ }^{14}$

It is unsurprising that the migrant workers should have been invisible to the state. It has been insufficiently recognized that a high proportion of workers in Indian cities are circular migrants, moving between village homes and urban centers-in contrast with the earlier experience of urbanization and industrialization in the West, in which labor moved on a permanent basis. ${ }^{15}$ Relatively little attention has been paid to these workers, except by a handful of scholars, prominent among them the Dutch sociologist Jan Breman, who draws on his fifty-some years of ethnographic research in western India. In India, he has shown, "A new class of nowhere people has emerged, forced to drift between what passes for 'home' and a place of 'work' (and who) In their marginality . . seem to pose no threat to the vested interests of capital and its agents."16

But Breman and the few others who have taken an interest in such migrant workers have been uncertain of the numbers of those involved, with estimates in the literature ranging from thirty million to a hundred million or more. Now, with the COVID-19 pandemic, the scale of migration for work within India was thrust upon the attention of government and a middle-class public that has long preferred to push poverty out of sight. ${ }^{17}$ But the numbers, still, are uncertain. The economist Ravi Strivastava, a member of the National Commission on Enterprises in the Unorganised Sector (2004-09), which had studied labor questions in depth, suggested that the numbers of short-term and circular migrants in the informal economy might be sixty million to sixty-

${ }^{12}$ Sidharth Ravi, "Migrant Labourers Holed Up in Their Dwellings without Work, Access to Food," The Hindu, March 26, 2020, https://www.thehindu.com/news/national/coronavirus-lockdownmigrant-labourers-holed-up-in-their-dwellings-without-work-access-to-food/article31172867.ece (accessed July 24, 2020).

${ }^{13}$ Rohan Venkataramakrishnan, "The Indian Police Must Understand That Coronavirus Cannot Be Beaten with a Lathi," Scroll.in, March 26, 2020, https://scroll.in/article/957269/the-indian-policeneed-to-understand-that-coronavirus-cannot-be-beaten-with-a-lathi (accessed July 24, 2020)

${ }^{14}$ See, for example, "Exodus of Migrant Workers out of Delhi Continues Unabated," The Hindu, March 29, 2020, https://www.thehindu.com/news/national/coronavirus-exodus-of-migrantworkers-out-of-delhi-unabated-but-police-block-their-entry-into-anand-vihar-isbt/article31198725. ece (accessed July 24, 2020)

${ }^{15}$ Sushant Singh, “An Expert Explains: 'India’s Coronavirus Lockdown Will Spotlight Migrants' Role in Cities," Indian Express, April 3, 2020, https://indianexpress.com/article/explained/ migrant-labour-role-india-lockdown-tariq-thachil-6343869/ (accessed July 24, 2020).

${ }^{16}$ Jan Breman, Capitalism, Inequality and Poverty in India (Cambridge: Cambridge University Press, 2019), xi-xii.

${ }^{17}$ Nandini Gooptu, The Politics of the Urban Poor in Early Twentieth Century India (Cambridge: Cambridge University Press, 2001). 
five million, and with accompanying family members, perhaps more than a hundred million. ${ }^{18}$ On May 14, Finance Minister Nirmala Sitharaman announced a scheme for the relief of migrant workers, numbering them at eighty million (about one-fifth of the labor force).

There has been a general reluctance across middle-class Indian society to recognize the contributions of migrant workers. Instead, these workers commonly lack rights as citizens, such as having access to rations under India's public distribution system (PDS) their ration cards being valid, if they hold them at all, only in their home locations. They are denied the franchise in their places of work, and they are often harassed and mistreated, liable to experience repression at the hands of the police. Many of them are also employed under conditions that Breman calls "neo-bondage"-tied to employers or contractors or to the "jobbers" (intermediaries) who employ them, in long-term debt relations that are shorn of the reciprocal obligations associated with the idea of "patronage."19 Such circular migrant workers come disproportionately from rural areas in poor parts of the country, particularly from eastern Uttar Pradesh and Bihar and from Jharkhand, Chhattisgarh, and Madhya Pradesh. And they come especially from Scheduled Caste and Scheduled Tribe backgrounds or from among the Other Backward Classes. ${ }^{20}$ They are uniformly poor. At least 89 percent of the labor force of India is made up of those who are either informally employed or self-employed, and two-thirds of them do not receive the 375 rupee (Rs) daily wage or earn this amount, which was recommended as the national minimum wage to meet basic household needs at 2017-18 prices. $^{21}$

It has been estimated that as many as thirty million migrant workers were on the move-a movement of people dwarfing even that which took place at the time of Partition. ${ }^{22}$ The numbers shocked the government into urgent action. On March 26, a relief package equivalent to US $\$ 22.5$ billion was announced, and on March 29, Prime Minister Modi made a televised address in which he asked forgiveness for having caused people so much trouble-though he also said, counting on the adulation of very many of the people, "My conscience tells me you will definitely forgive me." The relief package was brought in under a scheme that had been started in December 2016, for the confidential declaration of "unaccounted wealth"- and seen by some as having created a kind of a slush fund called the Pradhan Mantri (Prime Minister) Garib Kalyan Yojana

\footnotetext{
${ }^{18}$ Ravi Srivastava, "No Relief for the Nowhere People," The Hindu, May 4, 2020, https://www.thehindu.com/opinion/op-ed/no-relief-for-the-nowhere-people/article31495460.ece (accessed July 24, 2020)

${ }^{19}$ Breman, Capitalism, Inequality and Poverty in India.

${ }^{20}$ Sai Balakrishnan, "India’s Brutally Uneven Development Patterns Are Mapped in Routes Migrant Workers Are Taking Home," Scroll.in, May 26, 2020, https://scroll.in/article/962925/theroutes-migrant-workers-are-taking-home-reflect-indias-brutally-uneven-geographical-development (accessed July 24, 2020)

${ }^{21}$ K. P. Kannan, "COVID-19 Lockdown: Protecting the Poor Means Keeping the Economy Afloat," EPW Engage, April 3, 2020, https://www.epw.in/engage/article/covid-19-lockdown-protecting-poormeans-keeping-indian-economy-afloat (accessed July 24, 2020).

${ }^{22}$ See the estimate made by migration expert Chinmay Tumbe: https:/twitter.com/chinmaytumbe/ status/1266366333811187715?lang=en (accessed July 24, 2020).
} 
(PMGKY). The PMGKY package included provision for a food grain ration for eight hundred million Indians, as well as small cash payments to different groups of vulnerable people and increased wages (from Rs 182 per day to Rs 202) for those employed in the public employment scheme, MGNREGS (Mahatma Gandhi National Rural Employment Guarantee Scheme), although by this time many states had already closed MGNREGS work sites. The food grain ration was for those holding ration cards who were already entitled to 5 kilograms per month at a fixed price; it added a further 5 kilograms free of charge, together with 1 kilogram of local pulses (per family) for a period of three months. ${ }^{23}$

While the PMGKY was welcomed as a step in the right direction, it was also found to be distinctly miserly. It was pointed out that the funds allocated to the package amounted to only about 0.8 percent of gross domestic product (GDP), much lower than in most other countries, and that a significant proportion of the planned expenditure was made up by funds that had already been committed. New funding was limited (to not much more than 0.5 percent of GDP). There were concerns about the numbers of poor people without ration cards, estimated to be more than a hundred million. ${ }^{24}$ The amounts of the cash transfers that were part of the package were small, in any case, and narrowly targeted-although at least one businessman had advocated, in the course of an interaction with the prime minister before the lockdown on March 24, that the government should make an immediate payment of Rs 5,000 to all those aged twenty-five and over. ${ }^{25}$ As the economist Jean Dreze put it, too, whether of food or cash, disbursement would be a huge challenge. The record of Indian governments, after all, in reaching the poorest people is not strong. ${ }^{26}$

Thus it was that the government was called upon to do much more. Two winners of the Nobel Prize in economics, Amartya Sen and Abhijit Banerjee, joined with the former governor of the Reserve Bank of India, Raghuram Rajan, in arguing, "We need to do what it takes to reassure people that the society does care and that their minimum well-being should be secure." They proposed that the government should be ready to use the 77 million tonnes of food in the stores of the Food Corporation of India; issue temporary ration cards and universalize distribution — so that anybody would be able to go to the

\footnotetext{
${ }^{23}$ Contrast these provisions with the recommendation of Madhura Swaminathan that "we need to immediately ensure universal rationing with an expanded food basket" (emphasis added). See "Shift to Upscaling Food Rationing Now," The Hindu, March 28, 2020, https://www.thehindu. com/opinion/lead/shift-to-upscaling-food-rationing-now/article31186819.ece (accessed July 24, 2020).

${ }^{24}$ Meghana Mungikar, Jean Dreze, and Reetika Khera estimate that 108.4 million are excluded from the PDS, basically because the Centre continues to use outdated 2011 population data. Reported by Scroll Staff, "100 Million Indians Fall through Gaps in Food Safety Net," Scroll.in, April 15, 2020, https://scroll.in/article/959235/100-million-indians-fall-through-gaps-in-food-safetynet-economists-urge-rethink-on-covid-19-relief (accessed July 27, 2020).

${ }^{25}$ This is reported by Kannan, "COVID-19 Lockdown."

${ }^{26}$ Jean Dreze, "The Finance Minister's COVID-19 Package Is Helpful, but There Are Gaping Holes in It," Economic Times, March 28, 2020, https://economictimes.indiatimes.com/news/ economy/policy/view-the-finance-ministers-covid-19-relief-package-is-helpful-but-there-are-gapingholes-in-it/articleshow/74853103.cms (accessed July 24, 2020).
} 
ration shops; and that in making cash transfers, the government should err on the side of inclusion. ${ }^{27}$ A good many others argued in the same vein. ${ }^{28}$

Meanwhile, what was actually happening to the millions of people whose livelihoods were threatened? There were many reports by journalists, some of them harrowing, but quantitative data were scanty. Some researchers in Delhi were able to conduct telephone surveys with people in 413 households in industrial areas spread across the city that they had been studying since May 2019. They found that 91 percent of the men were unable to work; 85 percent earned no income; 53 percent of those employed before March 24 had not received a salary; and 35 percent reported not getting adequate food. ${ }^{29}$ Another survey, conducted by Azim Premji University, of 3,970 workers across eighteen states found that 67 percent had lost their livelihoods. ${ }^{30} \mathrm{~A}$ report released on April 15 by the Stranded Workers Action Network, which had contacted 11,000 migrant workers, showed that 96 percent had not received rations from the government; 70 percent had not received any cooked food; and 89 percent had not been paid by their employers. As the journalist Kabir Agarwal, who reported these findings, put it, "as hunger grows the fear of starvation is real." ${ }^{31}$ In the same report, Agarwal noted a reliance on philanthropy in the government's submission to the Supreme Court in the first week of April. This showed that in thirteen states, NGOs had set up more food camps and fed more people than the state governments. An affidavit submitted to the Supreme Court by the Union government in early April also stated that 69 percent of the shelters and relief camps that had been set up for migrant workers were located in Kerala alone. ${ }^{32}$

The limitations of the implementation of the relief package of March 26 were exposed in the government's own reports in early May: two hundred million ration card holders did not get grain under the PMGKY in April, and only 18 percent of

${ }^{27}$ Amartya Sen, Raghuram Raja, and Abhijit Banerjee, "Huge Numbers May Be Pushed into Dire Poverty or Starvation ... We Need to Secure Them," Indian Express, April 17, 2020, https://indian express.com/article/opinion/coronavirus-india-lockdown-economy-amartya-sen-raghuram-rajanabhijit-banerjee-6364521/ (accessed July 24, 2020)

${ }^{28}$ These included former governors of the Reserve Bank of India, D. Subbarao, and C. Rangarajan. See Swaminathan, "Shift to Upscaling Food Rationing Now"; Kannan, "COVID-19 Lockdown"; and Aiyar, "The State Needs to Step Up."

${ }^{29}$ Surveys conducted by Farzana Afridi, Amrita Dhillon, and Sanchari Roy, "A Phone Survey Reveals How the COVID-19 Crisis Has Affected The Urban Poor," The Wire, April 23, 2020, https://thewire.in/rights/how-has-covid-19-crisis-affected-the-urban-poor (accessed July 28, 2020); and "Lockdown Survey," The Wire, May 11, 2020, https://thewire.in/rights/urban-poor-lockdownphone-survey (accessed July 28, 2020).

${ }^{30}$ Arpita Raj, “67\% Workers Lost Livelihood in COVID-19 Lockdown,” The Quint, May 12, 2020, https:/www.thequint.com/coronavirus/67-workers-lost-livelihood-over-covid-19-lockdown-survey (accessed July 24, 2020).

${ }^{31}$ Kabir Agarwal, "Coronavirus Lockdown: As Hunger Grows, the Fear of Starvation Is Real," The Wire, April 16, 2020, https://thewire.in/rights/covid-19-100-million-hunger-pds-universal (accessed July 24,2020 ).

${ }^{32}$ Srinivasan Ramani, “Coronavirus Package: Will Migrant Workers Benefit from the Centre’s Measures?,” The Hindu, May 17, 2020, https://www.thehindu.com/news/national/coronavirus-packagewill-migrant-workers-benefit-from-the-centres-measures/article31603590.ece (accessed July 24, 2020). 
those entitled had received the promised ration of pulses. ${ }^{33}$ Thanks to the shutdown of work sites until April 20, the increased wages for work under MGNREGS that had been promised (and had actually been agreed in an annual exercise preceding the lockdown ${ }^{34}$ ) were of little benefit to most. The number of person days of work created in April 2020 the month in which employment under the scheme normally begins to climb toward its peak in May and June-was the lowest in any single month (by a long way) for ten years. ${ }^{35}$ All the while, the long-standing problems of Indian farmers, and the evidence of declining incomes in the period before the pandemic, were compounded by difficulties, for many, in securing labor for the harvesting of the winter crop and by problems of marketing. ${ }^{36}$ And, at the beginning of May, adding insult to injury, three state governments, all of them constituted by the BJP-Uttar Pradesh, Madhya Pradesh, and Gujarat-announced changes to labor laws that removed some of the most basic protection for workers. How far these changes would encourage investment—which apparently was the intention-seemed doubtful to business commentators. ${ }^{37}$

There was then eager anticipation across society-from businesspeople anxious to know how the government proposed reviving the economy to poor people worrying about their livelihoods - when the prime minister announced a (purportedly) massive new stimulus and relief package in another televised address to the nation on May 12. The package, Modi said, was to be of 20 lakh crores of rupees (US\$264 billion, equivalent to nearly 10 percent of India's GDP) and aimed “at our farmers and labourers." It was to be focused on "land, labour, liquidity and laws" and to reflect an economic philosophy, going forward, of self-reliance. But the prime minister left the details to be explained to the nation over the following five days, in a series of announcements made by Finance Minister Sitharaman. ${ }^{38}$ As the dust began to settle after all these announcements, it became clear that the new package satisfied very few Indians, save those

\footnotetext{
${ }^{33}$ Reports by Kabir Agarwal, "200 Million Ration Card Holders Did Not Get Grain Under PM Garib Kalyan in April," The Wire, May 7, 2020, https://thewire.in/rights/pm-garib-kalyan-200million-ration-card-holders-food-grains (accessed July 24, 2020); and Samyak Pandey, "Modi Govt Promised Free Pulses to 20 Crore, Only 18\% Have Got Them So Far," ThePrint, May 10, 2020, https://theprint.in/india/governance/modi-govt-promised-free-pulses-to-20-crore-only-18have-got-them-so-far/417200/ (accessed July 24, 2020).

${ }^{34}$ Reetika Khera, "From Apathy to Action," The Hindu, March 30, 2020, https://www.thehindu. com/opinion/op-ed/from-apathy-to-action/article31200357.ece (accessed July 24, 2020),

${ }^{35}$ Manish Kumar, "Choking the Lifeline of the Rural Economy: MGNREGS during the COVID-19 Lockdown” (Monograph 20/2, Society for Social Economic Research, 2020), http://archive.indianstatistics.org/sserwp/sserwp2002.pdf (accessed July 24, 2020).

${ }^{36}$ Vikas Rawal, Manish Kumar, Ankur Verma, and Jesim Pais, "COVID-19 Lockdown: Impact on Agriculture and Rural Economy" (Monograph 20/3, Society for Social and Economic Research, 2020), https://www.networkideas.org/wp-content/uploads/2020/06/sserwp2003.pdf, (accessed July 24, 2020).

${ }^{37}$ See a positive editorial comment in Economic Times, May 8 2020. For editorial criticism, see The Hindu, May 9; Rohan Venkataramakrishnan, "The Political Fix: Why Are Indian States Junking Labour Laws in the Middle of the COVID-19 Crisis?," Scroll.in, May 11, 2020, https:/scroll.in/ article/961585/the-political-fix-why-are-indian-states-junking-labour-laws-in-the-middle-of-thecovid-19-crisis (accessed July 24, 2020).

${ }^{38}$ The detailed proposals are summarized in a document of the Government of India, https://www. thehindu.com/news/resources/article31606441.ece/binary/AtmaNirbharBharatFullPresentationPart5.pdf (accessed May 21, 2020).
} 
concerned above all about fiscal discipline. The emphasis was overwhelmingly on the supply side of the economy and focused on the "liquidity" part of the deal that Modi had promised, being mostly about making capital available on easy terms. It was reported in the Financial Times that "economists say the true value of the stimulus is between 1.5 and 1.8 per cent of GDP — a far cry from Mr Modi’s promises."39 The package offered, in the end, very little in the way of relief. Income and wage support were to be kept to a minimum, and there was certainly reason, in consequence, for concern about the demand side of the post-pandemic economy. ${ }^{40}$ For India's poor people, the most important announcements were that eighty million migrant workers were to receive 5 kilograms of food grains per person and 1 kilogram of pulses per family, free, for two months; that the implementation of a "one nation, one ration card" scheme, which was intended to enable migrant workers and their family members to access PDS benefits anywhere in the country, was to be completed by March 2021; and that the budget for the MGNREGS would be increased over the budget allocation by almost two-thirds. The first two of these measures still fell short of the universalization of the PDS and the expansion of the food basket that had been advocated by Sen, Banerjee, Rajan, and so many others.

There was very little indication, therefore, at the time of this writing (late May 2020) that the needs of most Indians who are self-employed in generally poorly remunerated activities_including agriculture-or who are informally employed, including the very large numbers of circulatory migrants, had figured at all prominently in the calculations of the Modi government. There had been only token signs of compassion, for all Modi's promise of a package aimed at "our farmers and labourers." If further proof was needed of the callousness of the government, it came at the beginning of May, when the government at last gave in to demands from state governments and from workers themselves to allow migrant workers to travel back home by rail. There was confusion about how the migrants' travel was to be paid for, and there is no doubt that in some cases, they were required to pay for their tickets themselves. It was pointed out how this contrasted with the huzzah surrounding the Vande Bharat program for flying Indians stuck abroad back home. ${ }^{41}$

None of this should be a matter for surprise, because the Indian state has never given priority to the well-being of working people. For all of Jawaharlal Nehru's fine words before the Constituent Assembly about "giving every Indian the fullest opportunity to develop himself according to his capacity," India’s public expenditure on education and

\footnotetext{
${ }^{39}$ Amy Kazmin, “Modi’s Coronavirus ‘Stimulus' Leaves Business and Investors Deflated,” Financial Times, May 19, 2020.

${ }^{40}$ Prem Shankar Jha, “Modi’s Stimulus Package Is a Gigantic Confidence Trick,” The Wire, May 18, 2020, https://thewire.in/political-economy/modis-stimulus-package-is-a-gigantic-confidence-trickplayed-on-the-people-of-india (accessed July 24, 2020); "A Matter of Relief: On Economic Stimulus Package," The Hindu, May 19, 2020, https:/www.thehindu.com/opinion/editorial/a-matter-ofrelief-on-economic-stimulus-package/article31617547.ece (accessed July 24, 2020)

${ }^{41}$ Lav Agarwal, "Fact Check: No the Centre Isn't Paying for Migrant Workers' Train Journeys Home," The Wire, May 6, 2020, https://thewire.in/government/indian-railways-migrant-workersfare (accessed July 24, 2020); Shekhar Gupta, "Vande Bharat vs. Bharat ke bande," ThePrint, May 9, 2020, https:/theprint.in/national-interest/vande-bharat-vs-bharat-ke-bande-can-narendramodi-be-losing-his-political-touch-so-soon/417506/ (accessed July 24, 2020).
} 
health-the basic conditions for the realization of Nehru's promise-has remained at much lower levels than in comparable countries. The state's neglect of the many millions of people who have been displaced by big infrastructure projects, perhaps as many as 60 million since independence, and certainly disproportionately from among the Scheduled Castes and Scheduled Tribes, is a further shocking marker of a lack of compassionindeed, of the invisibility — of the most deprived should-be citizens. When, at last, thanks to pressure from reformers both within government and outside it in civil society, India began to legislate social and economic rights_-including the rights to work and to foodin the first decade of this century, it was in the face of fierce official opposition. ${ }^{42}$ Having set up a special body, the National Commission on Enterprises in the Unorganised Sector, to make policy recommendations concerning the activities and the livelihoods of the great majority of the labor force, the Congress-headed government led by Manmohan Singh disregarded and even disparaged its advice.

One of the striking features of Indian democracy is that democratically elected governments and the bureaucracies that are supposed to implement their policies are remarkably unresponsive to people's needs, though there are important variations among state governments. That of Kerala usually stands out, as it has done in the course of the coronavirus pandemic. ${ }^{43}$ There is a perverse, negative spiral in the way in which democracy works in India that has to do with the relationships between politicians and the bureaucracy. The latter, though capable in exceptional circumstances of performing very effectively, on an everyday basis functions through rigid following of rules, discouraging active problem-solving. A politician who sought to win election with promises regarding the delivery of public services would not get very far. Those promises would not be believed, because of the way the bureaucracy functions. In this context, one way in which a politician may seek to win and maintain support is through populist appeals; it may also be accomplished by the delivery of benefits to particular supporters, perhaps fellow caste members. From the point of view of politicians, being able to control selective benefits through clientelism, using the resources of the state, is a more reliable way of building electoral support-and of realizing rents for themselves - than standing on a policy platform including promises about the delivery of public goods. ${ }^{44}$

Recent analyses of the prevailing cleavages in electoral politics seem to confirm this, showing the rise of religious divisions and the persistence of strong caste-based cleavages, while education, income, and occupation have become less significant in determining voters' choices. ${ }^{45}$ The conventional understanding of ideological divisions from the

\footnotetext{
${ }^{42}$ See John Harriss, Craig Jeffrey, and Trent Brown, India: Continuity and Change in the 21st Century (Cambridge: Polity Press, 2020), chapter 8.

${ }^{43}$ On the lack of responsiveness of government, see Harriss, Jeffrey, and Brown, India, chapter 8. On the Kerala response to the COVID-19 crisis, see Patrick Heller, "A Virus, Social Democracy and Dividends for Kerala," The Hindu, April 18, 2020, https:/www.thehindu.com/opinion/lead/a-virussocial-democracy-and-dividends-for-kerala/article31370554.ece. (accessed July 24, 2020)

${ }^{44}$ N. C. Saxena, "Governance Reforms in India," in Reinventing Social Democratic Development: Insights from Indian and Scandinavian Comparisons, eds. Olle Tornquist and John Harriss (Copenhagen: NIAS Press, 2016), 131-67.

${ }^{45}$ This is the analysis of Abhijit Banerjee, Amory Gethin, and Thomas Piketty, "Growing Cleavages in India: Evidence from the Changing Structure of Electorates, 1962-2014," Economic and
} 
experience of the West, between "right" (sympathetic to capital and the middle classes and to market-driven economics) and "left" (supportive of working people and state intervention), has little purchase in the Indian context.

Aiyar's remark that "a democracy that treats its citizens with callousness and a complete lack of compassion cannot survive" calls into question what sort of democracy India has. As has been said by a good many scholars, in India the meaning of democracy has been reduced to "elections," and the institutions of liberal democracy have been weakened over a long period, from well before the first election of Narendra Modi in 2014, but with increasing force since then. ${ }^{46}$ By 2020 , according to the Varieties of Democracy (V-Dem) Report, which aggregates the assessments of expert observers of countries' performance on a wide variety of democratic indicators, "India is on the verge of losing its status as a democracy due to the severe shrinking of space for the media, civil society, and the opposition under Prime Minister Modi's government." ${ }^{47}$ There is no doubt that the trends that the V-Dem Report refers to have been carried further in the context of the COVID-19 crisis. As noted earlier, the government has been able to use the circumstances of the crisis to quash the opposition that mobilized against its plans for the amendment of the citizenship laws and to arrest critical activists. A group of former judges and senior lawyers argued that the Supreme Court is complicit in the abrogation of democratic practice, of which it was guilty at the time of Indira Gandhi's infamous Emergency. ${ }^{48}$ The government has carried further the centralization of power, against the principles of Indian federalism but in line with the earlier demands of the RSS (Rashtriya Swayamsevak Sangh) that India should be a unitary state. ${ }^{49}$

The Indian government that has so greatly weakened Indian democracy, while also displaying "a complete lack of compassion," is not only led but personified by Narendra Modi. It is not at all surprising to read reports of those who have suffered as a result of the lockdown saying such things as "Modi will take care of us," ${ }^{00}$ because he has used the crisis, with enormous panache, yet again, to project himself as the guardian of the country, even while the actions that he has taken and the policies that he has enjoined are supportive mainly of the middle classes and of business interests. On the occasion

Political Weekly 54, no. 11 (2019): 34-44. Their analysis is broadly consistent with the work of Pradeep K. Chhibber and Rahul Verma, Ideology and Identity: The Changing Party Systems of India (Oxford: Oxford University Press, 2018).

${ }^{46}$ See Harriss, Jeffrey and Brown, India, chapter 7.

${ }^{47}$ V-Dem Institute, Autocratization Surges, Resistance Grows: Democracy Report 2020 (Gothenburg: University of Gothenburg, 2020), 6.

48" Supreme Court Sacrificed Core Principles during Lockdown, Says CJA," The Hindu, May 13, 2020, https://www.thehindu.com/news/national/supreme-court-sacrificed-core-principles-duringlockdown-says-cjar/article31577320.ece (accessed July 24, 2020); Prashant Bhushan, "The Supreme Court Is Locked Down and Justice Is in 'Emergency' Care," The Wire, April 28, 2020, https://thewire.in/law/lockdown-supreme-court-justice (accessed July 24, 2020).

${ }^{49}$ Prabhat Patnaik, “A Dangerous Course," https://coronapolicyimpact.org/2020/05/08/a-dangerouscourse/ (accessed July 24, 2020).

${ }^{50}$ See, for example, S. Pandey, “'At least Modi Is Feeding Us'-Migrants, Poor Say Lockdown Is Tough but Give PM a Thumbs Up," ThePrint, April 20, 2020, https:/theprint.in/india/at-leastmodi-is-feeding-us-migrants-poor-say-lockdown-is-tough-but-give-pm-a-thumbs-up/404892/ (accessed July 24, 2020). 
of the "janata curfew" on March 22, and again on April 5, when, in response to his call in another address to the nation, millions across the country lit candles and lamps and flashed torches at 9:00 p.m. to "ward off the darkness of coronavirus," Modi demonstrated his control over very large numbers of the Indian people (even if it was the case that the Ministry of Human Resource Development exercised some compulsion on students and teachers over the latter event).

National solidarity in confronting the pandemic called for obedience to the dictates of the leader. Polling evidence-though such evidence is particularly suspect in Indiashows that Modi has an exceptionally high approval rating. According to data presented by the Economist ${ }^{51}$ his level of popular approval, already higher than that of any other major leader, had increased still further, to 82 percent in May 2020. Though it is usually the case that political leaders gain in approval at times of crisis, only to lose it later, Modi's ratings are exceptionally high. He is not absolutely impregnable, and there seems little doubt that he was losing support in the last months of 2018 and in early 2019. But then came the suicide bomb attack on a convoy of security forces at Pulwama and the attack by the Indian air force on Balakot in Pakistan in the aftermath. The attack may have been a farce, but it allowed Modi to project his image as the defender of the nation - and to win a great parliamentary majority that otherwise probably would have eluded him. His particular brand of authoritarian populism, marshaling majoritarian Hindu sentiment, has worked so well that a government displaying very little compassion, which is rapidly becoming an electoral autocracy, retains support among a substantial share of the people of India.

\section{Acknowledgments}

I am grateful for their comments to Barbara Harriss-White, Craig Jeffrey, Nate Roberts, Alpa Shah, Ashwin Subramanian, and two anonymous referees-and I regret that constraints of space have meant that I have been unable to respond to them all.

51“Covid-19 Has Given Most World Leaders a Temporary Rise in Popularity," The Economist, May 9, 2020, https://www.economist.com/graphic-detail/2020/05/09/covid-19-has-given-mostworld-leaders-a-temporary-rise-in-popularity (accessed July 24, 2020). 